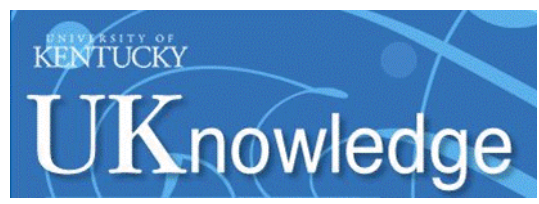

University of Kentucky UKnowledge

$11-5-2017$

\title{
Tobacco's Minor Alkaloids: Effects on Place Conditioning and Nucleus Accumbens Dopamine Release in Adult and Adolescent Rats
}

Julie A. Marusich

RTI International

Mahesh Darna

University of Kentucky

A. George Wilson

University of Kentucky

Emily D. Denehy

University of Kentucky, emily.denehy@uky.edu

See next page for additional authors

Right click to open a feedback form in a new tab to let us know how this document benefits you. Follow this and additional works at: https://uknowledge.uky.edu/ps_facpub

Part of the Pharmacy and Pharmaceutical Sciences Commons 


\title{
Tobacco's Minor Alkaloids: Effects on Place Conditioning and Nucleus Accumbens Dopamine Release in Adult and Adolescent Rats
}

\author{
Digital Object Identifier (DOI) \\ https://doi.org/10.1016/j.ejphar.2017.08.029 \\ Notes/Citation Information \\ Published in European Journal of Pharmacology, v. 814, p. 196-206. \\ (C) 2017 Elsevier B.V. All rights reserved.
}

This manuscript version is made available under the CC-BY-NC-ND 4.0 license https://creativecommons.org/licenses/by-nc-nd/4.0/.

The document available for download is the author's post-peer-review final draft of the article.

\section{Authors}

Julie A. Marusich, Mahesh Darna, A. George Wilson, Emily D. Denehy, Amanda Ebben, Agripina G. Deaciuc, Linda P. Dwoskin, Michael T. Bardo, Timothy W. Lefever, Jenny L. Wiley, Chad J. Reissig, and Kia J Jackson 


\title{
Tobacco's minor alkaloids: effects on place conditioning and nucleus accumbens dopamine release in adult and adolescent rats
}

\author{
Julie A. Marusich ${ }^{a}$, Mahesh Darna ${ }^{b}$, A. George Wilson ${ }^{c}$, Emily D. Denehy $^{c}$, Amanda Ebben $^{b}$, \\ Agripina G. Deaciuc ${ }^{b}$, Linda P. Dwoskin ${ }^{b}$, Michael T. Bardo ${ }^{c}$, Timothy W. Lefevera, Jenny L. \\ Wiley $^{a}$, Chad J. Reissig ${ }^{d}$, and Kia J. Jackson ${ }^{d}$ \\ ${ }^{a}$ RTI International, 3040 Cornwallis Road, Research Triangle Park, NC 27709 USA \\ ${ }^{b}$ College of Pharmacy, University of Kentucky, Lexington, KY 40536-0596 USA \\ ${ }^{\circ}$ Center for Drug Abuse Research Translation, University of Kentucky, Lexington, KY 40536-0509 \\ USA
}

dU.S. Food and Drug Administration, Center for Tobacco Products, 10903 New Hampshire Ave., Silver Spring, Maryland 20993 USA

\section{Abstract}

Tobacco products are some of the most commonly used psychoactive drugs worldwide. Besides nicotine, alkaloids in tobacco include cotinine, myosmine, and anatabine. Scientific investigation of these constituents and their contribution to tobacco dependence is less well developed than for nicotine. The present study evaluated the nucleus accumbens dopamine-releasing properties and rewarding and $/$ or aversive properties of nicotine $(0.2-0.8 \mathrm{mg} / \mathrm{kg})$, cotinine $(0.5-5.0 \mathrm{mg} / \mathrm{kg})$, anatabine $(0.5-5.0 \mathrm{mg} / \mathrm{kg})$, and myosmine $(5.0-20.0 \mathrm{mg} / \mathrm{kg})$ through in vivo microdialysis and place conditioning, respectively, in adult and adolescent male rats. Nicotine increased dopamine release at both ages, and anatabine and myosmine increased dopamine release in adults, but not adolescents. The dopamine release results were not related to place conditioning, as nicotine and cotinine had no effect on place conditioning, whereas anatabine and myosmine produced aversion in both ages. While the nucleus accumbens shell is hypothesized to play a role in strengthening drug-context associations following initiation of drug use, it may have little involvement in the motivational effects of tobacco constituents once these associations have been acquired. Effects of myosmine and anatabine on dopamine release may require a fully developed dopamine system, since no effects of these tobacco alkaloids were observed during adolescence. In summary, while anatabine and myosmine-induced dopamine release in nucleus accumbens may play a role in tobacco dependence in adults, the nature of that role remains to be elucidated.

\section{Keywords}

anatabine; conditioned place preference; cotinine; microdialysis; myosmine; nicotine 


\subsection{Introduction}

Tobacco products are commonly used psychoactive drugs that have led to a high public health toll (HHS, 2014; WHO, 2013). Although nicotine is believed to be the primary addictive constituent in tobacco, there are $>8,400$ other constituents in tobacco smoke (Rodgman and Perfetti, 2008), and the contribution of these constituents to tobacco dependence is not yet understood. In addition to nicotine, other tobacco constituents evaluated for addictive potential include nicotine metabolites and minor alkaloids (e.g., cotinine, myosmine, and anatabine) (Clemens et al., 2009; Hall et al., 2014), flavor additives (e.g., menthol) that enhance nicotine's pharmacological effects (Alsharari et al., 2015; Biswas et al., 2016), and $\beta$-carbolines that inhibit monoamine oxidase (Smith et al., 2015). Pharmacological effects of tobacco products are mediated by this chemical cocktail (Henningfield and Zeller, 2003). Since initiation of tobacco use often occurs during adolescence (Lydon et al., 2014), it is important to understand the pharmacological effects of tobacco constituents during this developmental period.

Nicotine activates the mesolimbic dopamine reward pathway. Nicotine-evoked dopamine release in the nucleus accumbens (NAc) depends on activation of nicotinic receptors in the midbrain ventral tegmental area (Nisell et al., 1994). Moreover, the stimulant and rewarding effects of nicotine depend on ventral tegmental area-mediated dopamine release in the NAc (Gotti et al., 2010). In contrast to nicotine, however, no studies have examined the doseeffect relationships for other tobacco constituents on dopamine release in the NAc in rodents.

Nicotine-evoked dopamine release in NAc is thought to be the primary mechanism leading to hyperactivity and reward. To measure reward, place conditioning is often used to evaluate the degree of association between the rewarding (conditioned place preference, CPP) or aversive (conditioned place aversion, CPA) properties of a drug and the environment in which these properties are experienced repeatedly (Carr et al., 1989; Tzschentke, 1998). Tobacco constituent cues (e.g., rewarding, aversive, smell, taste) may become associated with environmental and social conditions in which tobacco is consumed, leading to associations that may persist in the tobacco-free state. This associative learning may impede attainment and maintenance of abstinence.

Nicotine CPP has been demonstrated in adult and adolescent rats (Le Foll and Goldberg, 2005; Natarajan et al., 2011; Vastola et al., 2002); however, negative findings also have been reported (Belluzzi et al., 2004; Shoaib et al., 1994; Shram et al., 2006; Vastola et al., 2002). To date, no studies have reported tobacco constituent CPP; however, nicotine CPP is less likely to develop in rats pre-exposed to tobacco smoke compared to rats pre-exposed to nicotine alone (de la Pena et al., 2014). This suggests that non-nicotine constituents may diminish the rewarding effects of tobacco.

While it is known that nicotine activates the mesolimbic dopamine reward system, it is unclear if other tobacco constituents have similar or different effects, or if dopamine activation differs between adolescence and adulthood. This study was designed to reduce this gap. Furthermore, locomotor activity and CPP were assessed to determine if age- 
dependent differences in dopamine activation among tobacco constituents were associated with differences in dopamine-relevant behaviors.

\subsection{Materials and Methods}

\subsection{Subjects}

Male Sprague-Dawley rats, obtained from Harlan Laboratories (Indianapolis, IN, USA), were housed in age-matched pairs in polycarbonate cages. Rats arrived at two ages: adult [postnatal day (PND) 60 or greater] and adolescent (PND 21-23). Rats were maintained in a temperature-controlled environment with a 12-hour light-dark cycle, and had free access to rodent chow and water in their home cages. All studies were carried out in accordance with guidelines published in the Guide for the Care and Use of Laboratory Animals (National Research Council, 2011), the ARRIVE guidelines, and in accordance with the Institutional Animal Care and Use Committee (IACUC) of the Food Drug Administration (FDA) and with other federal and state regulations. Additionally, place conditioning and in vivo microdialysis studies were performed in accordance with the IACUCs associated with RTI and the University of Kentucky, respectively.

\subsection{Drugs}

(-)-Nicotine, (-)-cotinine, myosmine, and (+)-methamphetamine were purchased from Sigma-Aldrich (St. Louis, MO). ( \pm )-Anatabine was purchased from Matrix Scientific (Columbia, SC). These compounds were dissolved in sterile saline (USP grade), and the $\mathrm{pH}$ was adjusted to approximately neutral ( $\mathrm{pH} \sim 7$ ), as necessary. Doses of tobacco constituents were expressed as $\mathrm{mg} / \mathrm{kg}$ of free base, and methamphetamine was expressed as $\mathrm{mg} / \mathrm{kg}$ of the $\mathrm{HCl}$ salt. Nicotine, cotinine, myosmine, anatabine, and methamphetamine were injected in a volume of $1 \mathrm{ml} / \mathrm{kg}$. Acepromazine, xylazine, and ketamine were obtained from Butler Schein (Dublin, OH). Carprofen and isoflurane were obtained from Merritt (Ridgefield, CT) and Cardinal Health (Dublin, OH), respectively.

\subsection{Equipment}

Microdialysis experiments were conducted in Plexiglas chambers with a pine bedding floor measuring $25 \mathrm{~cm} \times 44 \mathrm{~cm} \times 38 \mathrm{~cm}$ for the experiments using adults, and measuring $25 \mathrm{~cm} \times$ $44 \mathrm{~cm}$ by $24 \mathrm{~cm}$ for experiments using adolescents. A swivel and tether system (BAS, Indianapolis, IN) was attached to the side of the chamber and connected to a microsyringe pump (KD Scientific, Holliston, MA, Model KDS250). Microdialysis samples were analyzed for dopamine using high performance liquid chromatography coupled with electrochemical detection (HPLC-ECD, ESA Inc., Chelmsford, MA) as previously described (Meyer et al., 2013). The computer-controlled HPLC-EC system consisted of a solvent delivery pump (ESA model 582), a Coulochem III 5200A electrochemical detector, and an ESA 542 HPLC autosampler and a 5014B analytical cell and 5020 guard cell. The guard cell was set at $+350 \mathrm{mV}$, electrode 1 at $-150 \mathrm{mV}$, and electrode 2 at $+220 \mathrm{mV}$. The mobile phase consisted of $90 \mathrm{mM} \mathrm{NaH} \mathrm{PO}_{4} \mathrm{H}_{2} \mathrm{O}, 50 \mathrm{mM}$ citric acid, $1.7 \mathrm{mM}$ 1-octanesulfonic acid, 50 $\mu \mathrm{M}$ EDTA, and $10 \%$ acetonitrile ( $\mathrm{pH} 3.0$ adjusted with phosphoric acid; flow rate was 0.6 $\mathrm{ml} / \mathrm{min}$ ). Samples (20 $\mu \mathrm{l})$ were auto-injected onto an analytical column (ESA MD $150 \times 3$, 
$150 \mathrm{~mm} \times 3.2 \mathrm{~mm}$ ) and peaks were compared with external standards using an ESA Chromatography Data System (EZChrom Elite, ESA Chelmsford, MA).

Place conditioning sessions were conducted in an automated system comprised of threecompartment chambers, with each side measuring $27.5 \mathrm{~cm} \times 22 \mathrm{~cm} \times 31.5 \mathrm{~cm}$ and the center measuring $14 \mathrm{~cm} \times 22 \mathrm{~cm} \times 31.5 \mathrm{~cm}$. Chambers were surrounded by an array of $4 \times 16$ photocell infrared beams. The equipment was interfaced with San Diego Systems software (model 6610-001-A, San Diego, CA). Compartments were separated from each other by removable doors, and each compartment had distinct environmental cues. The equipment was verified to be unbiased for both adolescent and adult rats before conditioning sessions began, i.e., when averaged across animals of either age, amount of time spent was not different between side compartments, indicating lack of systematic side preference.

\subsection{Experimental Design}

Upon arrival, rats were assigned to a single dose of a single compound or saline $(\mathrm{n}=8-$ 14/age/group). Nicotine $(0.2-0.8 \mathrm{mg} / \mathrm{kg})$, cotinine $(0.5-5.0 \mathrm{mg} / \mathrm{kg})$, anatabine $(0.5-5.0 \mathrm{mg} /$ $\mathrm{kg})$, and myosmine $(5.0-20.0 \mathrm{mg} / \mathrm{kg})$ were evaluated. Also, methamphetamine $(0.3-1.0$ $\mathrm{mg} / \mathrm{kg}$ ) served as a positive control in the place conditioning study. Nicotine doses were chosen based on their ability to induced CPP in rats (Le Foll and Goldberg, 2005), and increase dopamine release in rat NAc (Adermark et al., 2015; Rahman et al., 2008; Silvagni et al., 2008). Minor tobacco alkaloid doses were chosen based on their ability to alter locomotor activity or intracranial self-stimulation (ICSS) threshold (Harris et al., 2015; Wiley et al., 2015), or substitute for nicotine in drug discrimination (Goldberg et al., 1989). Subcutaneous (s.c.) administration was used for all tobacco constituents to minimize first pass metabolism (Matta et al., 2007). Methamphetamine was administered intraperitoneally (i.p.).

\subsection{Microdialysis Surgery}

Surgeries for microdialysis were performed under aseptic conditions on PND 76-77 (adults) or PND 30-31 (adolescents), using previously described methods (Meyer et al., 2013; Rahman et al., 2007). Anesthetic cocktails were based on age differences in pharmacokinetic effects of ketamine and xylazine (Veilleux-Lemieux et al., 2013). Adult rats were anesthetized by administering (i.p.) $0.44-0.54 \mathrm{ml} / \mathrm{kg}$ body weight of a cocktail containing $0.75 \mathrm{mg} / \mathrm{kg}$ acepromazine, $7.5 \mathrm{mg} / \mathrm{kg}$ xylazine, and $75 \mathrm{mg} / \mathrm{kg}$ ketamine. Adolescent rats were anesthetized by administering (i.p.) $0.15 \mathrm{ml}$ of a cocktail containing $8 \mathrm{mg} / \mathrm{kg}$ xylazine and $60 \mathrm{mg} / \mathrm{kg}$ ketamine. Depth of anesthesia was monitored by eye blink response to corneal stimulation and muscle twitch response to strong pinch of the toe and tail. If responses were observed, supplementary anesthetic $1-4 \%$ isoflurane/oxygen inhalant was employed until responses were absent. Rats were placed in a stereotaxic apparatus (Stoelting, Wood Dale, IL), and a guide cannula (MD-2251, 22 gauge, BAS, Indianapolis, IN) was implanted unilaterally in the NAc shell, with coordinates adjusted for each age (Paxinos and Watson, 1986). For adults, coordinates were $\mathrm{A} / \mathrm{P}+1.6, \mathrm{~L}+0.8$ and $\mathrm{D} / \mathrm{V}-6.0$; for adolescents, coordinates were $\mathrm{A} / \mathrm{P}+1.6 ; \mathrm{L}+1.0$ and $\mathrm{D} / \mathrm{V}-4.8$. The guide cannula was secured to the skull with dental acrylic and jeweler's screws. To minimize discomfort and pain, rats were 
given carprofen ( $5 \mathrm{mg} / \mathrm{kg}$, s.c., once daily) on the day prior to surgery and for a minimum of 3 days after the surgery. Following surgery, rats were allowed to recover for 2 days.

\subsection{Microdialysis Procedure}

On PND 79 (adults) or PND 33 (adolescents), a microdialysis probe was connected to a microsyringe pump via PE10 tubing that perfused $(1.2 \mu \mathrm{l} / \mathrm{min})$ artificial cerebral spinal fluid (aCSF; consisting of $145 \mathrm{mM} \mathrm{NaCl}, 2.7 \mathrm{mM} \mathrm{KCl}, 1 \mathrm{mM} \mathrm{MgCl}_{2}, 1.2 \mathrm{CaCl}_{2}$ and $2 \mathrm{mM}$ $\mathrm{Na}_{2} \mathrm{HPO}_{4} \mathrm{pH}$ adjusted to 7.4) at a continuous flow rate. Probes were inserted into the guide cannula and rats were connected to a swivel system by a flexible leash attached to a neck collar. Rats were habituated to the Plexiglas chamber for at least $3 \mathrm{~h}$ prior to collection of the baseline dialysate samples. Baseline samples were collected into polyethylene microfuge tubes containing $5 \mu \mathrm{l}$ of $0.1 \mathrm{~N}$ perchloric acid at $20 \mathrm{~min}$ intervals for $60 \mathrm{~min}$, prior to administration of drug or saline. Sample collection continued for $3 \mathrm{~h}$ following injection, which was sufficient for extracellular dopamine to return to baseline levels (Rahman et al., 2007; Rahman et al., 2008). Following each microdialysis experiment, brains were removed and flash frozen in Chromasolv ${ }^{\circledR}$ (Sigma-Aldrich, St. Louis MO). Brains were sectioned into coronal slices, mounted onto slides, and stained for visualization. Microdialysis probe placement in the NAc was confirmed, and data from rats with misplaced probes were excluded from analysis.

\subsection{HPLC Analysis of Dopamine}

Samples $(25 \mu \mathrm{l})$ were loaded into a sample loop and injected onto a reverse-phase analytical column (MD-150 × $3.2 \mathrm{~mm}, \mathrm{C}_{18}$ column; ThermoScientific, PA, USA). The mobile phase consisted of $90 \mathrm{mM} \mathrm{NaH} \mathrm{PO}_{4} \mathrm{H}_{2} \mathrm{O}, 50 \mathrm{mM}$ citric acid monohydrate, $1.7 \mathrm{mM} 1$ octanesulfonic acid, $50 \mu \mathrm{M}$ EDTA, and $13 \%$ acetonitrile $(\mathrm{pH} 3.0$ adjusted with $2 \mathrm{~N} \mathrm{NaOH}$; flow rate was $0.5 \mathrm{ml} / \mathrm{min}$ ). Retention times of dopamine standards were used to identify the dopamine peak. Chromatograms were integrated, compared with the standards and analyzed using an ESA Chromatography Data System (EZChrom Elite, Chelmsford, MA).

\subsection{Place Conditioning Procedure}

The place conditioning procedure was adapted from previous work that evaluated CPP with nicotine in adult and adolescent rats (Le Foll and Goldberg, 2005; Natarajan et al., 2011; Vastola et al., 2002) and contained three phases: pre-conditioning (habituation), conditioning (acquisition), and post-conditioning (expression). The pre-conditioning phase occurred on Day 1, during which rats were allowed to explore all compartments of the CPP apparatus during a 15-min session. Adults were tested on PND 66 (Day 1) and adolescents were tested on PND 27 (Day 1). Time spent in each compartment was recorded and initial preference was defined as the side compartment in which the rat spent the greatest amount of time.

The conditioning phase occurred on Days 2-9, with 30 min sessions conducted each day. During this phase, rats were injected with their assigned tobacco constituent on 4 days and with saline on the alternating 4 days. The group of saline control rats was injected with saline on all 8 days. Half the rats in each group were assigned randomly to receive an injection of the designated tobacco constituent on the first day of the conditioning phase, and the other half received a saline session on the first day. During conditioning sessions, rats 
were confined to a single side compartment immediately after injection. Assignment to conditioning compartments was biased; i.e., injection of saline was associated with the side of the chamber that the individual rat preferred during the pre-conditioning session and injection of the constituent was associated with the non-preferred side. The postconditioning phase was conducted on Day 10, and consisted of a single 15-min session that was identical to the pre-conditioning session. Amount of time spent in each compartment was recorded. In addition, locomotor activity was recorded during all pre-, post-, and conditioning sessions.

\subsection{Microdialysis Data Analysis}

Dopamine levels at baseline were calculated by comparing peak heights from samples taken prior to any pretreatment with external standard curves. Data were recorded as peak height for dopamine for each sample collected following administration of tobacco constituent or saline. Data obtained following injection were expressed as a percent of baseline (average of pretreatment samples) and analyzed using a mixed model ANOVA (age $\times$ dose $\times$ time), with age and dose as between-subjects factors, and time as a repeated measures factor.

Subsequently, time course data were analyzed for each group using separate one-factor repeated measures ANOVAs, with follow up Dunnett's tests. To determine the effects of each dose of tobacco constituent, Dunnett's tests were conducted between each dose of tobacco constituent and vehicle at each time point. In some cases, to probe individual time points between adolescent and adult rats, independent two-tailed t-test comparisons were performed. Also, data were calculated for dopamine as area under the curve (AUC) using the trapezoidal rule (GraphPad Prizm 5.0 Software Inc., San Diego, CA), and expressed as percent change from baseline following administration of the tobacco constituent. AUC values were analyzed by two-factor ANOVA (Age $\times$ Dose) followed by post hoc t-tests.

\subsection{Place Conditioning Data Analysis}

Time spent in each compartment during the pre- and post-conditioning tests was recorded, and the number of Y-axis photocell beam breaks during all sessions was collected. Number Cruncher Statistical Systems software (Hintze, 2004) was used for all analyses. The postconditioning only CPP/CPA index was used as the primary measure of preference, and was calculated as the time spent in the tobacco constituent- or methamphetamine-associated compartment minus time spent in the saline-associated compartment during postconditioning (Kota et al., 2007; Natarajan et al., 2011). CPP was indicated by a positive number and CPA was indicated by a negative number. For each constituent, a separate factorial (age $\times$ dose) ANOVA was used to compare the CPP/CPA measure across ages and doses. Tukey-Kramer post hoc tests were used to compare means as appropriate.

Locomotor activity during drug conditioning sessions was analyzed by separate two-way mixed model ANOVAs for each constituent, with dose as the between-subjects factor and number of tobacco constituent exposures (1-4) as the repeated measures factor. TukeyKramer post hoc tests were used to compare means. Significance level for all ANOVAs and post hoc tests was $\alpha=0.05$. 


\subsection{Results}

\subsection{Baseline dopamine levels}

Dopamine recovered from NAc dialysate was measured in both adults and adolescents injected with saline. Dopamine concentration (mean \pm S.E.M.) in dialysate across the first 3 sampling periods prior to the saline injection was $4.53 \pm 0.60 \mathrm{pg} / 25 \mu \mathrm{l}$ for adults and 4.86 $\pm 0.20 \mathrm{pg} / 25 \mu \mathrm{l}$ for adolescents. There was no significant difference in baseline dopamine concentration between ages.

\subsection{Nicotine-induced dopamine release}

The time course of the effect of nicotine on dopamine release from the NAc is shown in Figure 1a and $\mathrm{b}$. Nicotine increased dopamine release [main effect of drug: $F(1,45)=$ 22.044, $P<0.05]$. While the time course of nicotine-induced dopamine release appeared visually different for each age (Fig. 1a and $b$ ), the time $\times$ age $\times$ nicotine interaction was not significant. Separate within-age analyses revealed that nicotine increased dopamine release for both ages [main effect of drug; adults: $F(1,23)=8.31, P<0.05$; adolescents:

$F(1,22)=13.71, P<0.05]$. Further analyses of dose revealed an effect of nicotine in both ages [adults: $\mathrm{t}(22)=-3.88, P<0.05$; adolescents: $\mathrm{t}(22)=-2.45, P<0.05$ ]. Thus, there was an overall nicotine-induced increase in extracellular dopamine concentration in the NAc at both ages. Although there was a strong trend for adults to show a greater nicotine-induced dopamine response than adolescents at the 20 min time point, this difference did not reach statistical significance using a post hoc independent $\mathrm{t}$-test $[\mathrm{t}(22)=1.81, P=0.08]$, likely due to the high variability associated with the adults.

The effect of nicotine on NAc dopamine release expressed as AUC is shown in Figure 1c. Nicotine significantly increased release compared to saline [main effect of drug: $F(1,47)=$ 20.57, $P<0.05$ ], with no significant drug $\times$ age interaction. Thus, no reliable age-related difference in nicotine-induced dopamine release was found.

\subsection{Cotinine-induced dopamine release}

There were no significant main effects of cotinine dose or age on dopamine release, and no significant dose $\times$ age interaction (data not shown). Thus, under these conditions, cotinine was inactive in both adults and adolescents. When dopamine release was expressed as AUC, there was no main effect of cotinine dose, age, or dose $\times$ age interaction (data not shown). Thus, cotinine was inactive.

\subsection{Anatabine-induced dopamine release}

The time course of effects of anatabine on dopamine release from the NAc is shown in Figure 2a and $\mathrm{b}$. Anatabine increased dopamine release [main effect of drug: $F(3,75)=5.55, P$ $<0.05]$. Collapsed across age, 1 and $5 \mathrm{mg} / \mathrm{kg}$ significantly increased dopamine release. Separate analyses for each age group showed that anatabine increased dopamine release in adults $[F(3,37)=5.18, P<0.05]$ at 1 and $5 \mathrm{mg} / \mathrm{kg}$, but did not increase dopamine in adolescents. 
The dose effect of anatabine on dopamine release expressed as AUC is shown in Figure 2c and d. Anatabine increased dopamine release [main effect of dose: $F(3,82)=4.33, P<0.05$ ]. Collapsed across age, 1 and $5 \mathrm{mg} / \mathrm{kg}$ anatabine increased dopamine release. Similar to the time course results, separate within-age comparisons showed that anatabine increased dopamine release in adults $[F(3,40)=4.17, P<0.05]$, but not in adolescents.

\subsection{Myosmine-induced dopamine release}

The time course of effects of myosmine on dopamine release from the NAc is shown in Figure $3 \mathrm{a}$ and $\mathrm{b}$. The overall ANOVA revealed a significant main effect of dose $[F(3,75)=$ $3.109, P<0.05]$, but no significant dose $\times$ age interaction. Collapsed across age, post hoc comparisons revealed no significant effect at any dose. Separate analyses within each age showed a significant effect of dose in adults $[F(3,37)=3.49, P<0.05]$, but not adolescents.

The dose effect of myosmine on dopamine release from the NAc expressed as AUC is shown in Figure $3 \mathrm{c}$ and $d$. There was no effect of dose or dose $\times$ age interaction in the overall ANOVA; however, separate within-age analyses revealed a significant main effect of dose in adults $[F(3,40)=3.23, P<0.05]$, but not in adolescents. In adults, $20 \mathrm{mg} / \mathrm{kg}$ increased dopamine release. Thus, similar to the time course results, a myosmine-induced increase in dopamine release from the NAc was obtained in adults, but not in adolescents.

\subsection{Preference}

Comparisons of the post-conditioning only CPP/CPA index between ages for all tobacco constituents are shown in Figure 4. For nicotine, adolescents showed overall higher preference scores than adults [main effect of age: $F(1,76)=7.73, P<0.05$ ], but nicotine did not induce CPP or CPA for either age (compared to respective saline only condition) (Fig. 4a). Cotinine did not produce any significant effects for age or dose (Fig. 4b). In contrast, both anatabine and myosmine produced significant CPA for both ages [main effect of anatabine: $F(3,72)=12.42, P<0.05$; main effect of myosmine: $F(3,72)=10.41, P<0.05$ ] (Figs. 4c and 4d).

\subsection{Locomotor Activity}

For tobacco constituents, locomotor activity during drug conditioning sessions is shown in Figures 5-6. Initial exposure to $0.4-0.8 \mathrm{mg} / \mathrm{kg}$ nicotine decreased activity for adults compared to the saline group [dose $\times$ session interaction: $F(9,108)=8.20, P<0.05$ ] (Fig. 5a). Activity remained suppressed during session 2 for $0.8 \mathrm{mg} / \mathrm{kg}$ nicotine compared to the saline group; however, across sessions, all doses of nicotine successively increased activity in adult rats [main effect of session: $F(3,108)=36.53, P<0.05$ ]. While activity was relatively stable over time in the saline group, nicotine produced significant increases in activity during later drug sessions compared to session 1 [dose $\times$ session interaction: $F(9,108)=8.20, P<0.05]$ (Fig. 5a) .

As with adults, activity for adolescents administered saline was stable across sessions (Fig. 5c). In contrast to adults, nicotine did not decrease activity during initial sessions in adolescents; rather, $0.2-0.4 \mathrm{mg} / \mathrm{kg}$ nicotine significantly increased activity for all sessions, and $0.8 \mathrm{mg} / \mathrm{kg}$ increased activity during sessions $2-4$ (compared to saline) [dose $\times$ session 
interaction: $F(9,120)=2.01, P<0.05]$. Furthermore, $0.4-0.8 \mathrm{mg} / \mathrm{kg}$ nicotine produced sensitization, with increased activity across sessions [dose $\times$ session interaction: $F(9,120)=$ $2.01, P<0.05]$.

Cotinine produced few effects on locomotor activity (Figs. 5b and 5d). For adults (Fig. 5b), $5.0 \mathrm{mg} / \mathrm{kg}$ cotinine decreased activity during session 3 compared to the saline group [dose $\times$ session interaction: $F(9,108)=2.34, P<0.05]$ and $1.0-5.0 \mathrm{mg} / \mathrm{kg}$ cotinine decreased activity across sessions [dose $\times$ session interaction: $F(9,108)=2.34, P<0.05$ ] (Fig. 5b). While statistically significant, the magnitude of these differences was small compared to activity following nicotine. In adolescents (Fig. 5d), cotinine did not have any significant effects on activity.

Effects of anatabine on activity during the four conditioning sessions are shown in Figures $6 \mathrm{a}$ and c. In adults (Fig. $6 \mathrm{a}$ ), $5.0 \mathrm{mg} / \mathrm{kg}$ anatabine produced a sustained decrease in activity (compared to saline) [dose $\times$ session interaction: $F(9,108)=5.37, P<0.05$ ]. Injection of $0.5-1.0 \mathrm{mg} / \mathrm{kg}$ also decreased activity during some sessions. In addition, the initial reduction in activity induced by $1.0 \mathrm{mg} / \mathrm{kg}$ anatabine was augmented during subsequent sessions [dose $\times$ session interaction: $F(9,108)=5.37, P<0.05$ ]. Anatabine's effects in adolescents (Fig. 6c) were similar to those observed in adults, but less pronounced and not as sustained. In adolescents, $5.0 \mathrm{mg} / \mathrm{kg}$ decreased activity (compared to saline) during some sessions [dose $\times$ session interaction: $F(9,108)=4.54, P<0.05]$. Other doses did not alter activity compared to saline, although $1.0 \mathrm{mg} / \mathrm{kg}$ anatabine produced greater decrements in activity over time [dose $\times$ session interaction: $F(9,108)=4.54, P<0.05$ ].

Figure 6 also shows the effects of myosmine in adult and adolescent rats (Figs. 6b and 6d, respectively). In adults, myosmine significantly decreased activity (compared to saline) during all sessions [main effect of dose: $F(3,36)=30.32, P<0.05$ ]. In addition, session 3 decreased activity compared to session 1 [main effect of session: $F(3,108)=4.0, P<0.05$ ]. Similar to the other constituents, effects of myosmine on activity were less prominent in adolescents than in adults. In adolescents, $20.0 \mathrm{mg} / \mathrm{kg}$ myosmine decreased activity compared to saline, but only during session 4 [dose $\times$ session interaction: $F(9,108)=6.75, P$ $<0.05]$. In contrast, $5.0 \mathrm{mg} / \mathrm{kg}$ increased activity, but only during session 1 . Activity significantly decreased across sessions for $5.0 \mathrm{mg} / \mathrm{kg}$, suggesting tolerance developed to the acute activating effects of myosmine [dose $\times$ session interaction: $F(9,108)=6.75, P<0.05$ ]

\subsection{Methamphetamine CPP}

Because nicotine did not produce significant CPP in this study, methamphetamine was evaluated as a positive control. Preference data for methamphetamine are presented in Figure 7a. Both doses of methamphetamine produced significant CPP (compared to saline) in adolescent and adult rats [main effect of dose: $F(2,46)=7.79, P<0.05$ ].

Effects of methamphetamine on locomotor activity during conditioning sessions are shown in Figure $7 \mathrm{~b}$ and $\mathrm{c}$. In both ages, methamphetamine increased activity compared to the saline group [adult: $F(2,23)=60.88, P<0.05$; adolescent: $F(2,23)=92.76, P<0.05$ ]. The effect of $1.0 \mathrm{mg} / \mathrm{kg}$ methamphetamine was augmented across sessions in adolescents, indicating the 
development of locomotor sensitization [dose $\times$ session interaction: $F(6,69)=3.45, P<$ 0.05].

\subsection{Discussion}

As expected, nicotine increased extracellular dopamine in NAc in both adults and adolescents in the present study. Age differences in this effect were not apparent, which was surprising because early adolescent rats (PND 25) show lower plasma nicotine concentrations than adults when administered the same nicotine doses (Craig et al., 2014); however, only a single dose of nicotine was tested in the present study, and adolescents were tested later than in the previous study (PND 33 in the present study), which may have limited a full comparison of potential age differences. The present study is the first to examine effects of anatabine and myosmine on dopamine release in NAc in adult or adolescent rodents. Both constituents produced dose-dependent increases in extracellular dopamine in the NAc in adults, but not adolescents.

In contrast to nicotine, cotinine did not alter extracellular dopamine in the NAc in either age. These results contrast with a previous study showing that cotinine evokes dopamine release from striatal slices via a nicotinic receptor-mediated mechanism (Dwoskin et al., 1999; O'Leary et al., 2008). This discrepancy may be due to different cotinine levels in the brain following in vivo versus in vitro administration of cotinine. Further, cotinine binds to nicotinic receptors, although at a substantially lower potency and lower affinity than nicotine (Anderson and Arneric, 1994; O'Leary et al., 2008; Sloan et al., 1984; Vainio and Tuominen, 2001). Interestingly, cotinine also inhibits nicotine-induced dopamine release in the NAc in adult rats (Sziraki et al., 1999). Thus, cotinine appears to act as a partial agonist at nicotinic receptors in the mesolimbic system.

In the present study, nicotine produced neither preference nor aversion in adult rats, which is consistent with some studies (Belluzzi et al., 2004; Lenoir et al., 2015; Shoaib et al., 1994; Shram et al., 2006; Vastola et al., 2002), but not others (Dewey et al., 1999; Fudala and Iwamoto, 1986; Fudala et al., 1985; Le Foll and Goldberg, 2004; Le Foll and Goldberg, 2005; Le Foll et al., 2005). Additionally, nicotine did not induce place preference in adolescent rats. Differences in methodologies, such as larger sample sizes, exclusion of the most biased subjects, or individual subject housing, may account for the lack of place preference found in the present study compared to previous studies. More specifically, comparison of the present study to a seminal study by Le Foll and Goldberg (2005) that found nicotine-induced CPP suggests that nicotine-induced CPP may be dependent on a larger sample size, a shorter conditioning phase, and analysis of CPP between-groups instead of within-group. Therefore, nicotine CPP is likely dependent on the specific methods, doses, and age ranges employed (Le Foll and Goldberg, 2005; Tzschentke, 2007). The present study used methods and analyses that traditionally produce nicotine CPP. Despite this, nicotine CPP was not found. While studies of nicotine-induced CPP show inconsistent results, nicotine has produced more consistent effects on ICSS. Nicotine shifts brain stimulation reward thresholds in the ICSS procedure (Wise, 1996), with low and moderate doses reducing the threshold for maintenance of ICSS, and high doses elevating ICSS thresholds (Harris et al., 2015; Huston-Lyons and Kornetsky, 1992; LeSage et al., 
2016; Spiller et al., 2009). These results suggest that low doses of nicotine are rewarding while high doses are aversive.

Methamphetamine was evaluated to confirm that the present methods could detect CPP, since methamphetamine and amphetamine reliably induce CPP in adult and adolescent rodents (Mathews et al., 2010; Yates et al., 2013; Zakharova et al., 2009a; Zakharova et al., 2009b). In accordance with previous work, methamphetamine produced CPP in rats of both ages, which increases confidence that the procedures used in the present study were sensitive enough to detect the rewarding properties of stimulants that are readily self-administered by rats (Anker et al., 2012; Brennan et al., 2010; Kitamura et al., 2006).

Interestingly, nicotine's locomotor effects in adolescents resembled those of methamphetamine, with both drugs producing locomotor sensitization. In contrast, adult rats exhibited a biphasic locomotor response to nicotine, with decreased activity initially, and increased activity later. Hence, although initial nicotinic effects differed across ages, sensitization occurred in both ages. Sensitization is associated with activation of brain reward pathways (Vanderschuren and Kalivas, 2000; Vezina et al., 2007). Therefore, given the present results, the abuse liability of nicotine may be more related to psychostimulant effects than place conditioning effects.

Like nicotine, cotinine did not induce $\mathrm{CPP}$ or CPA in either age; however, the highest dose of cotinine decreased locomotor activity in adults, in accordance with past research (Wiley et al., 2015). Cotinine shares interoceptive effects with nicotine, as evidenced in drug discrimination studies (Goldberg et al., 1989; Takada et al., 1989). Collectively, these results show that, while the pharmacological profiles of cotinine and nicotine are overlapping, they are not identical.

In contrast to nicotine, anatabine and myosmine produced pronounced CPA, suggesting that they are aversive at the doses tested. Furthermore, both compounds dose-dependently decreased locomotor activity in adult rats, in accordance with past research (Wiley et al., 2015). Although anatabine increased dopamine release in adults, it does not maintain reliable self-administration when substituted for nicotine in rodents (Caine et al., 2014) or non-human primates (Desai et al., 2016; Mello et al., 2014), nor does it show rewarding effects in CPP (present study) or ICSS (Harris et al., 2015). While myosmine has not been examined for self-administration, it has aversive effects in CPP (present study) and ICSS (Harris et al., 2015). Combined, these results suggest that increases in dopamine release in the NAc produced by the minor tobacco alkaloids anatabine and myosmine were not sufficient to produce CPP or locomotor sensitization. Alternatively, it is possible that some non-dopaminergic mechanism of action of anatabine and myosmine, such as anatabine's interaction with nicotinic acetylcholine receptors (Maciuk et al., 2008), may override the dopamine-releasing effect, thus obscuring any potential rewarding effect. Unfortunately, any neuropharmacological action of these tobacco constituents beyond an interaction with nicotinic receptors remains largely unknown.

Dopamine release is involved in drug reward (Di Chiara, 1999; Spanagel and Weiss, 1999), and is a necessary component in initiation of drug taking (Kalivas and Volkow, 2005). Thus, 
there is a contradiction between the current microdialysis and CPP results for nicotine, and for myosmine and anatabine (in adult rodents). At least two factors may explain this discrepancy. First, in the present study, dopamine release was measured in the NAc shell. Dopamine D1 receptors in this region play a role in the acquisition of nicotine-induced CPP (Acquas et al., 1989; Spina et al., 2006), and lesions in the medial shell reduce expression of nicotine-induced CPP (Sellings et al., 2008), suggesting that dopamine release in the shell may contribute to nicotine's rewarding effects. However, other brain areas may modulate the rewarding and aversive properties of nicotine. For example, lesions in the NAc core increased CPP magnitude and abolished conditioned taste aversion (Sellings et al., 2008), suggesting that this area may regulate nicotine's aversive effects. Thus, performance in the place preference procedure may be influenced by a balance of rewarding and aversive processes mediated differentially in the shell and core of the NAc. Further work is needed targeting the NAc core in adults and adolescents to definitively address this question.

Second, the apparent disconnect between increased dopamine release in the NAc shell and expression of drug reward in the present study may be due to the different conditions under which these outcomes were evaluated. Dopamine release was measured immediately after an acute injection of the tobacco constituent, whereas place conditioning was measured in a drug-free state after repeated administration of the tobacco constituent. Dopamine release in the NAc shell is activated by unconditioned stimuli, but not conditioned stimuli (Di Chiara, 1999), both of which are key factors in place conditioning. Moreover, the NAc shell is hypothesized to strengthen drug-context associations following acute drug exposure, as in microdialysis, while it only plays a minor role in mediating the direct rewarding drug effects following repeated exposure, as in place conditioning (Di Chiara, 1999; Spanagel and Weiss, 1999). Consistent with this explanation, intracranial microinjection of dopamine receptor antagonists into NAc shell blocks acquisition, but not expression, of nicotine-induced CPP (Spina et al., 2006).

\subsection{Conclusion}

In summary, each of the tobacco constituents examined here produced a unique, age-related neurochemical and behavioral profile. In general, dopamine release results did not parallel the locomotor and place conditioning results. Differential age-related responses in accumbal dopamine release are likely due to ongoing adolescent brain development, with adults being more sensitive than adolescents to anatabine- and myosmine-induced release. In contrast, anatabine and myosmine produced CPA in both ages. Cotinine was relatively inactive, producing no change in either dopamine release or place preference in either age. These data suggest that adolescents, while behaviorally sensitive to these tobacco constituents, are less sensitive neurochemically, at least in NAc shell.

Future research should examine whether exposure to these constituents in adolescence manifests in neurobehavioral effects in adulthood. Tobacco constituent combinations should also be examined for their rewarding and dopamine releasing effects to further determine if these minor tobacco alkaloids play a role in tobacco dependence and inform the regulation of tobacco products. Interestingly, comparisons of self-administration of tobacco alkaloid combinations to self-administration of nicotine alone have shown mixed results, ranging 
from increased responding compared to nicotine alone to no effect compared to nicotine alone (Clemens et al., 2009; Smith et al., 2015). Therefore, anatabine and myosmine may play a role in tobacco dependence, but the nature of that role remains to be elucidated.

\section{Acknowledgements}

The authors thank Kateland Antonazzo, Daniel Barrus, Ricardo Cortes, Nikita Pulley, Andrew Rodewald, and Michael Wallgren for technical assistance. Research was generously supported by the Food and Drug Administration (contract number: HHSF223201310034I) and the National Institute of Health (grant number: T32DA016176). The authors have no conflicts of interest. The views and opinions expressed in this manuscript are those of the authors only, and do not necessarily represent the views, official policy, or position of the US Department of Health and Human Services, or any of its affiliated institutions or agencies.

\section{References}

Acquas E, Carboni E, Leone P, Di Chiara G (1989). Sch 23390 blocks drug-conditioned placepreference and place-aversion: Anhedonia (lack of reward) or apathy (lack of motivation) after dopamine-receptor blockade ? Psychopharmacology (Berl) 99: 151-155. [PubMed: 2572027]

Adermark L, Morud J, Lotfi A, Jonsson S, Soderpalm B, Ericson M (2015). Age-contingent influence over accumbal neurotransmission and the locomotor stimulatory response to acute and repeated administration of nicotine in wistar rats. Neuropharmacology 97: 104-112. [PubMed: 26079444]

Alsharari SD, King JR, Nordman JC, Muldoon PP, Jackson A, Zhu AZ, Tyndale RF, Kabbani N, Damaj MI (2015). Effects of menthol on nicotine pharmacokinetic, pharmacology and dependence in mice. PLoS One 10: e0137070. [PubMed: 26355604]

Anderson DJ, Arneric SP (1994). Nicotinic receptor binding of [3h]cytisine, [3h]nicotine and [3h]methylcarbamylcholine in rat brain. Eur J Pharmacol 253: 261-267. [PubMed: 8200419]

Anker JJ, Baron TR, Zlebnik NE, Carroll ME (2012). Escalation of methamphetamine selfadministration in adolescent and adult rats. Drug Alcohol Depend 124: 149-153. [PubMed: 22305912]

Belluzzi JD, Lee AG, Oliff HS, Leslie FM (2004). Age-dependent effects of nicotine on locomotor activity and conditioned place preference in rats. Psychopharmacology (Berl) 174: 389-395. [PubMed: 14740150]

Biswas L, Harrison E, Gong Y, Avusula R, Lee J, Zhang M, Rousselle T, Lage J, Liu X (2016). Enhancing effect of menthol on nicotine self-administration in rats. Psychopharmacology (Berl) 233: 3417-3427. [PubMed: 27473365]

Brennan KA, Colussi-Mas J, Carati C, Lea RA, Fitzmaurice PS, Schenk S (2010). Methamphetamine self-administration and the effect of contingency on monoamine and metabolite tissue levels in the rat. Brain Res 1317: 137-146. [PubMed: 19962371]

Caine SB, Collins GT, Thomsen M, Wright C, Lanier RK, Mello NK (2014). Nicotine-like behavioral effects of the minor tobacco alkaloids nornicotine, anabasine, and anatabine in male rodents. Exp Clin Psychopharmacol 22: 9-22. [PubMed: 24490708]

Carr GD, Fibiger HC, Phillips AG (1989). Conditioned place preference as a measure of drug reward In The neuropharmacological basis of reward. eds Liebman J, Cooper S Clarendon Press: Oxford, pp 264-319.

Clemens KJ, Caille S, Stinus L, Cador M (2009). The addition of five minor tobacco alkaloids increases nicotine-induced hyperactivity, sensitization and intravenous self-administration in rats. Int J Neuropsychopharmacol 12: 1355-1366. [PubMed: 19366487]

Craig EL, Zhao B, Cui JZ, Novalen M, Miksys S, Tyndale RF (2014). Nicotine pharmacokinetics in rats is altered as a function of age, impacting the interpretation of animal model data. Drug Metab Dispos 42: 1447-1455. [PubMed: 24980255]

de la Pena JB, Ahsan HM, Botanas CJ, Sohn A, Yu GY, Cheong JH (2014). Adolescent nicotine or cigarette smoke exposure changes subsequent response to nicotine conditioned place preference and self-administration. Behav Brain Res 272: 156-164. [PubMed: 24991754] 
Desai RI, Doyle MR, Withey SL, Bergman J (2016). Nicotinic effects of tobacco smoke constituents in nonhuman primates. Psychopharmacology (Berl) 233: 1779-1789. [PubMed: 26892379]

Dewey SL, Brodie JD, Gerasimov M, Horan B, Gardner EL, Ashby CR (1999). A pharmacologic strategy for the treatment of nicotine addiction. Synapse 31: 76-86. [PubMed: 10025686]

Di Chiara G (1999). Drug addiction as dopamine-dependent associative learning disorder. Eur J Pharmacol 375: 13-30. [PubMed: 10443561]

Dwoskin LP, Teng L, Buxton ST, Crooks PA (1999). (s)-(-)-cotinine, the major brain metabolite of nicotine, stimulates nicotinic receptors to evoke [3h]dopamine release from rat striatal slices in a calcium-dependent manner. J Pharmacol Exp Ther 288: 905-911. [PubMed: 10027825]

Fudala PJ, Iwamoto ET (1986). Further studies on nicotine-induced conditioned place preference in the rat. Pharmacol Biochem Behav 25: 1041-1049. [PubMed: 3786357]

Fudala PJ, Teoh KW, Iwamoto ET (1985). Pharmacologic characterization of nicotine-induced conditioned place preference. Pharmacol Biochem Behav 22: 237-241. [PubMed: 2858867]

Goldberg SR, Risner ME, Stolerman IP, Reavill C, Garcha HS (1989). Nicotine and some related compounds: Effects on schedule-controlled behaviour and discriminative properties in rats. Psychopharmacology (Berl) 97: 295-302. [PubMed: 2497478]

Gotti C, Guiducci S, Tedesco V, Corbioli S, Zanetti L, Moretti M, Zanardi A, Rimondini R, Mugnaini M, Clementi F, Chiamulera C, Zoli M (2010). Nicotinic acetylcholine receptors in the mesolimbic pathway: Primary role of ventral tegmental area $a 6 \beta 2 *$ receptors in mediating systemic nicotine effects on dopamine release, locomotion, and reinforcement. The Journal of Neuroscience 30: 5311-5325. [PubMed: 20392953]

Hall BJ, Wells C, Allenby C, Lin MY, Hao I, Marshall L, Rose JE, Levin ED (2014). Differential effects of non-nicotine tobacco constituent compounds on nicotine self-administration in rats. Pharmacol Biochem Behav 120: 103-108. [PubMed: 24560911]

Harris AC, Tally L, Muelken P, Banal A, Schmidt CE, Cao Q, LeSage MG (2015). Effects of nicotine and minor tobacco alkaloids on intracranial-self-stimulation in rats. Drug Alcohol Depend 153: 330-334. [PubMed: 26094184]

Henningfield JE, Zeller M (2003). Could science-based regulation make tobacco products less addictive? Yale Journal of Health Policy, Law, and Ethics 3: 127-138.

HHS (2014). The health consequences of smoking - 50 years of progress. A report of the surgeon general U.S. Department of health and human services, centers for disease control and prevention, national center for chronic disease prevention and health promotion, office on smoking and health, atlanta.

Hintze J (2004). Ncss and pass. Number cruncher stastical systemKaysville, UTHA WWW.NCSS.COM.

Huston-Lyons D, Kornetsky C (1992). Effects of nicotine on the threshold for rewarding brain stimulation in rats. Pharmacol Biochem Behav 41: 755-759. [PubMed: 1594644]

Kalivas PW, Volkow ND (2005). The neural basis of addiction: A pathology of motivation and choice. Am J Psychiatry 162: 1403-1413. [PubMed: 16055761]

Kitamura O, Wee S, Specio SE, Koob GF, Pulvirenti L (2006). Escalation of methamphetamine selfadministration in rats: A dose-effect function. Psychopharmacology (Berl) 186: 48-53. [PubMed: 16552556]

Kota D, Martin BR, Robinson SE, Damaj MI (2007). Nicotine dependence and reward differ between adolescent and adult male mice. J Pharmacol Exp Ther 322: 399-407. [PubMed: 17446302]

Le Foll B, Goldberg SR (2004). Rimonabant, a cb1 antagonist, blocks nicotine-conditioned place preferences. Neuroreport 15: 2139-2143. [PubMed: 15486497]

Le Foll B, Goldberg SR (2005). Nicotine induces conditioned place preferences over a large range of doses in rats. Psychopharmacology (Berl) 178: 481-492. [PubMed: 15765262]

Le Foll B, Goldberg SR, Sokoloff P (2005). The dopamine d3 receptor and drug dependence: Effects on reward or beyond? Neuropharmacology 49: 525-541. [PubMed: 15963538]

Lenoir M, Starosciak AK, Ledon J, Booth C, Zakharova E, Wade D, Vignoli B, Izenwasser S (2015). Sex differences in conditioned nicotine reward are age-specific. Pharmacol Biochem Behav 132: 56-62. [PubMed: 25735492] 
LeSage MG, Staley M, Muelken P, Smethells JR, Stepanov I, Vogel RI, Pentel PR, Harris AC (2016). Abuse liability assessment of an e-cigarette refill liquid using intracranial self-stimulation and selfadministration models in rats. Drug Alcohol Depend 168: 76-88. [PubMed: 27627814]

Lydon DM, Wilson SJ, Child A, Geier CF (2014). Adolescent brain maturation and smoking: What we know and where we're headed. Neurosci Biobehav Rev 45: 323-342. [PubMed: 25025658]

Maciuk A, Moaddel R, Haginaka J, Wainer IW (2008). Screening of tobacco smoke condensate for nicotinic acetylcholine receptor ligands using cellular membrane affinity chromatography columns and missing peak chromatography. J Pharm Biomed Anal 48: 238-246. [PubMed: 18187282]

Mathews IZ, Morrissey MD, McCormick CM (2010). Individual differences in activity predict locomotor activity and conditioned place preference to amphetamine in both adolescent and adult rats. Pharmacol Biochem Behav 95: 63-71. [PubMed: 20006968]

Matta SG, Balfour DJ, Benowitz NL, Boyd RT, Buccafusco JJ, Caggiula AR, Craig CR, Collins AC, Damaj MI, Donny EC, Gardiner PS, Grady SR, Heberlein U, Leonard SS, Levin ED, Lukas RJ, Markou A, Marks MJ, McCallum SE, Parameswaran N, Perkins KA, Picciotto MR, Quik M, Rose JE, Rothenfluh A, Schafer WR, Stolerman IP, Tyndale RF, Wehner JM, Zirger JM (2007). Guidelines on nicotine dose selection for in vivo research. Psychopharmacology (Berl) 190: 269319. [PubMed: 16896961]

Mello NK, Fivel PA, Kohut SJ, Caine SB (2014). Anatabine significantly decreases nicotine selfadministration. Exp Clin Psychopharmacol 22: 1-8. [PubMed: 24490707]

Meyer AC, Neugebauer NM, Zheng G, Crooks PA, Dwoskin LP, Bardo MT (2013). Effects of vmat2 inhibitors lobeline and gz-793a on methamphetamine-induced changes in dopamine release, metabolism and synthesis in vivo. J Neurochem 127: 187-198. [PubMed: 23875705]

Natarajan R, Wright JW, Harding JW (2011). Nicotine-induced conditioned place preference in adolescent rats. Pharmacol Biochem Behav 99: 519-523. [PubMed: 21600911]

National Research Council (2011) Guide for the care and use of laboratory animals. 8th edn. National Academies Press (US): Washington, D.C.

Nisell M, Nomikos GG, Svensson TH (1994). Systemic nicotine-induced dopamine release in the rat nucleus accumbens is regulated by nicotinic receptors in the ventral tegmental area. Synapse 16: 36-44. [PubMed: 8134899]

O’Leary K, Parameswaran N, McIntosh JM, Quik M (2008). Cotinine selectively activates a subpopulation of alpha3/alpha6beta2 nicotinic receptors in monkey striatum. J Pharmacol Exp Ther 325: 646-654. [PubMed: 18305015]

Paxinos G, Watson C (1986) The rat brain in stereotaxic coordinates. 2 edn. Academic Press: San Diego.

Rahman S, Neugebauer NM, Zhang Z, Crooks PA, Dwoskin LP, Bardo MT (2007). The effects of a novel nicotinic receptor antagonist n,n-dodecane-1,12-diyl-bis-3-picolinium dibromide (bpiddb) on acute and repeated nicotine-induced increases in extracellular dopamine in rat nucleus accumbens. Neuropharmacology 52: 755-763. [PubMed: 17097117]

Rahman S, Zhang Z, Papke RL, Crooks PA, Dwoskin LP, Bardo MT (2008). Region-specific effects of n,n'-dodecane-1,12-diyl-bis-3-picolinium dibromide on nicotine-induced increase in extracellular dopamine in vivo. Br J Pharmacol 153: 792-804. [PubMed: 18059317]

Rodgman A, Perfetti TA (2008) The chemical components of tobacco and tobacco smoke. CRC press.

Sellings LH, Baharnouri G, McQuade LE, Clarke PB (2008). Rewarding and aversive effects of nicotine are segregated within the nucleus accumbens. Eur J Neurosci 28: 342-352. [PubMed: 18702705]

Shoaib M, Stolerman IP, Kumar RC (1994). Nicotine-induced place preferences following prior nicotine exposure in rats. Psychopharmacology (Berl) 113: 445-452. [PubMed: 7862857]

Shram MJ, Funk D, Li Z, Le AD (2006). Periadolescent and adult rats respond differently in tests measuring the rewarding and aversive effects of nicotine. Psychopharmacology (Berl) 186: 201208. [PubMed: 16586088]

Silvagni A, Barros VG, Mura C, Antonelli MC, Carboni E (2008). Prenatal restraint stress differentially modifies basal and stimulated dopamine and noradrenaline release in the nucleus accumbens shell: An 'in vivo' microdialysis study in adolescent and young adult rats. Eur J Neurosci 28: 744-758. [PubMed: 18671739] 
Sloan JW, Todd GD, Martin WR (1984). Nature of nicotine binding to rat brain p2 fraction. Pharmacol Biochem Behav 20: 899-909. [PubMed: 6463074]

Smith TT, Schaff MB, Rupprecht LE, Schassburger RL, Buffalari DM, Murphy SE, Sved AF, Donny EC (2015). Effects of mao inhibition and a combination of minor alkaloids, beta-carbolines, and acetaldehyde on nicotine self-administration in adult male rats. Drug Alcohol Depend 155: 243252. [PubMed: 26257022]

Spanagel R, Weiss F (1999). The dopamine hypothesis of reward: Past and current status. Trends Neurosci 22: 521-527. [PubMed: 10529820]

Spiller K, Xi Z-X, Li X, Ashby CR, Callahan PM, Tehim A, Gardner EL (2009). Varenicline attenuates nicotine-enhanced brain-stimulation reward by activation of $\alpha 4 \beta 2$ nicotinic receptors in rats. Neuropharmacology 57: 60-66. [PubMed: 19393252]

Spina L, Fenu S, Longoni R, Rivas E, Di Chiara G (2006). Nicotine-conditioned single-trial place preference: Selective role of nucleus accumbens shell dopamine $\mathrm{d} 1$ receptors in acquisition. Psychopharmacology (Berl) 184: 447-455. [PubMed: 16341849]

Sziraki I, Sershen H, Benuck M, Lipovac M, Hashim A, Cooper TB, Allen D, Lajtha A (1999). The effect of cotinine on nicotine- and cocaine-induced dopamine release in the nucleus accumbens. Neurochem Res 24: 1471-1478. [PubMed: 10555788]

Takada K, Swedberg MD, Goldberg SR, Katz JL (1989). Discriminative stimulus effects of intravenous 1-nicotine and nicotine analogs or metabolites in squirrel monkeys. Psychopharmacology (Berl) 99: 208-212. [PubMed: 2508155]

Tzschentke TM (1998). Measuring reward with the conditioned place preference paradigm: A comprehensive review of drug effects, recent progress and new issues. Prog Neurobiol 56: 613672. [PubMed: 9871940]

Tzschentke TM (2007). Measuring reward with the conditioned place preference (cpp) paradigm: Update of the last decade. Addict Biol 12: 227-462. [PubMed: 17678505]

Vainio PJ, Tuominen RK (2001). Cotinine binding to nicotinic acetylcholine receptors in bovine chromaffin cell and rat brain membranes. Nicotine Tob Res 3: 177-182. [PubMed: 11403732]

Vanderschuren LJ, Kalivas PW (2000). Alterations in dopaminergic and glutamatergic transmission in the induction and expression of behavioral sensitization: A critical review of preclinical studies. Psychopharmacology (Berl) 151: 99-120. [PubMed: 10972458]

Vastola BJ, Douglas LA, Varlinskaya EI, Spear LP (2002). Nicotine-induced conditioned place preference in adolescent and adult rats. Physiol Behav 77: 107-114. [PubMed: 12213508]

Veilleux-Lemieux D, Castel A, Carrier D, Beaudry F, Vachon P (2013). Pharmacokinetics of ketamine and xylazine in young and old sprague-dawley rats. Journal of the American Association for Laboratory Animal Science : JAALAS 52: 567-570. [PubMed: 24041212]

Vezina P, McGehee DS, Green WN (2007). Exposure to nicotine and sensitization of nicotine-induced behaviors. Prog Neuropsychopharmacol Biol Psychiatry 31: 1625-1638. [PubMed: 17936462]

WHO (2013). Who report on the global tobacco epidemic 2013: Enforce bans on tobacco advertising, promotion and sponsorship. World Health Organization.

Wiley JL, Marusich JA, Thomas BF, Jackson KJ (2015). Determination of behaviorally effective tobacco constituent doses in rats. Nicotine Tob Res 17: 368-371. [PubMed: 25271188]

Wise RA (1996). Addictive drugs and brain stimulation reward. Annu Rev Neurosci 19: 319-340. [PubMed: 8833446]

Yates JR, Beckmann JS, Meyer AC, Bardo MT (2013). Concurrent choice for social interaction and amphetamine using conditioned place preference in rats: Effects of age and housing condition. Drug Alcohol Depend 129: 240-246. [PubMed: 23540449]

Zakharova E, Leoni G, Kichko I, Izenwasser S (2009a). Differential effects of methamphetamine and cocaine on conditioned place preference and locomotor activity in adult and adolescent male rats. Behav Brain Res 198: 45-50. [PubMed: 18996417]

Zakharova E, Wade D, Izenwasser S (2009b). Sensitivity to cocaine conditioned reward depends on sex and age. Pharmacol Biochem Behav 92: 131-134. [PubMed: 19032962] 

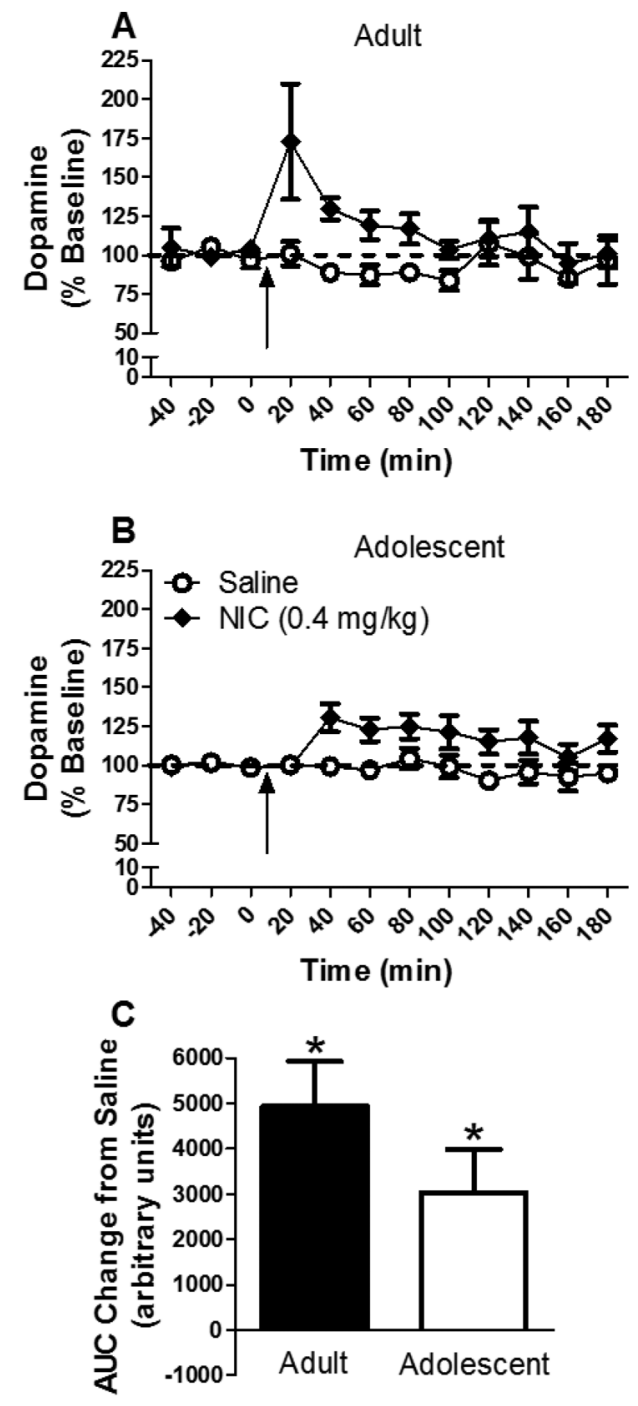

Figure 1.

Mean ( \pm S.E.M.) dopamine concentration in NAc dialysate in adults (panel A) and adolescents (panel B) as a percent of baseline for each time point following administration of saline or nicotine ( $n=13$ /group except adult saline $n=11$ and adolescent saline $n=12$ ).

Arrow indicates time of injection. Dashed line represents baseline, expressed as $100 \%$. Panel $\mathrm{C}$ shows area under the curve (AUC) following nicotine administration for each group expressed as a change from saline. * indicates significant difference from saline control. 

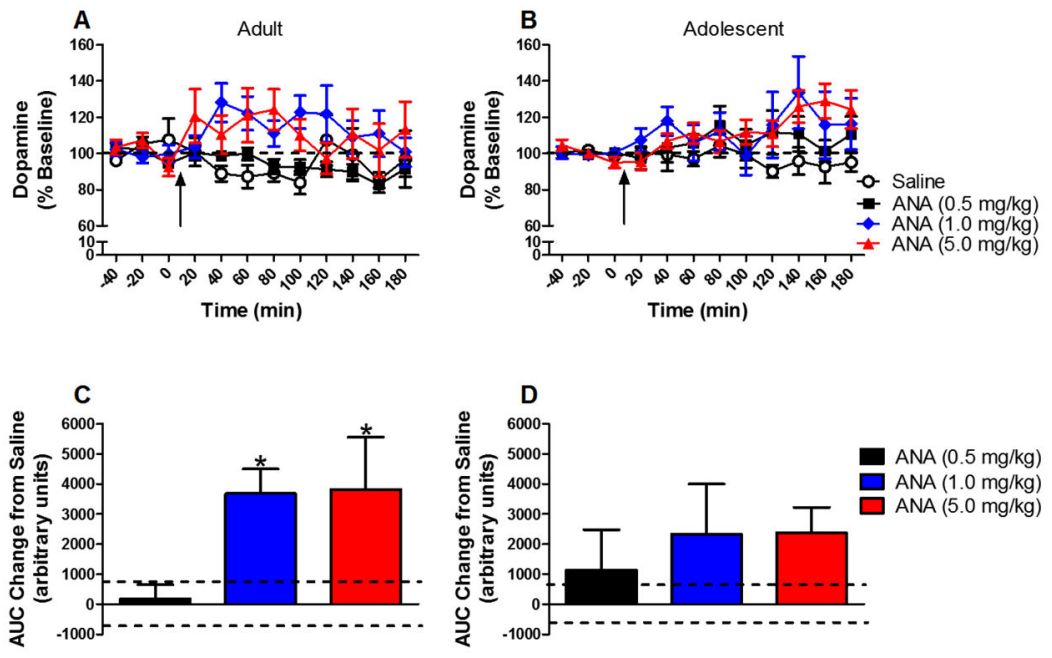

Figure 2:

Mean ( \pm S.E.M.) dopamine concentration in NAc dialysate in adults (panel A) and adolescents (panel B) as a percent of baseline for each time point following administration of saline or anatabine (ANA) ( $n=10$ /group except adult saline $n=11$ and adolescent saline $\mathrm{n}=12$ ). Arrow indicates time of injection. Dashed line represents baseline, expressed as $100 \%$. Panels C and D show mean ( \pm S.E.M.) area under the curve (AUC) in adults (panel C) and adolescents (panel D) following anatabine administration expressed as a change from saline. Dashed lines represent S.E.M. for saline. * indicates significant difference from saline control. 

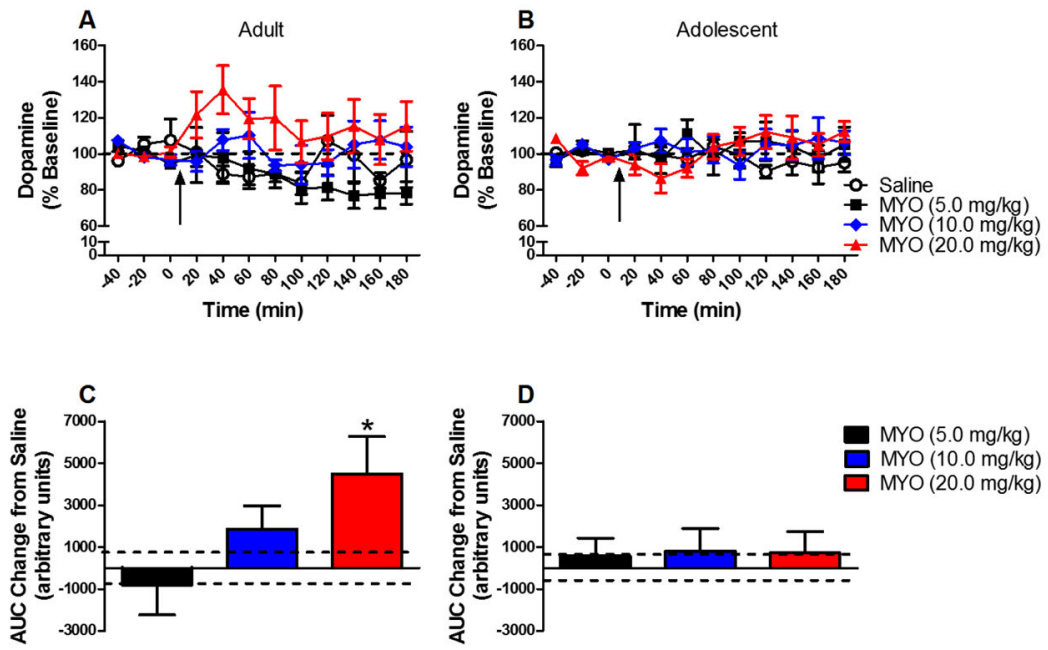

Figure 3:

Mean ( \pm S.E.M.) dopamine concentration in NAc dialysate in adults (panel A) and adolescents (panel B) as a percent of baseline for each time point following administration of saline or myosmine (MYO) ( $n=10$ /group except adult saline $n=11$ and adolescent saline $\mathrm{n}=12$ ). Arrow indicates time of injection. Dashed line represents baseline, expressed as $100 \%$. Panels C and D show mean ( \pm S.E.M.) area under the curve (AUC) in adults (panel C) and adolescents (panel D) following myosmine administration expressed as a change from saline. Dashed lines represent S.E.M. for saline. * indicates significant difference from saline control. 

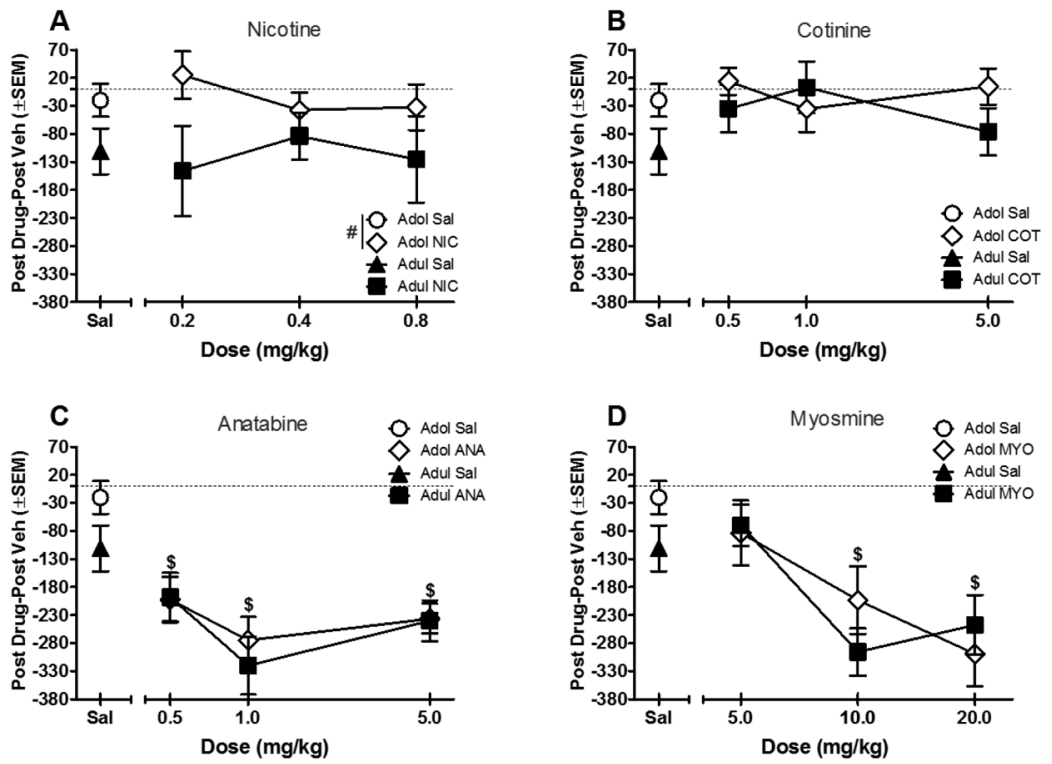

Figure 4.

Preference for each tobacco constituent, calculated as time spent in drug side minus time spent in vehicle side during the post-conditioning test $(n=10 /$ group except adolescent 0.2 nicotine $n=14$ ). Values below the horizontal line indicate aversion whereas values above the horizontal line indicate preference. \# indicates significant main effect of age compared to adult; $\$$ indicates significant main effect of dose compared to vehicle. Sal stands for saline vehicle. 

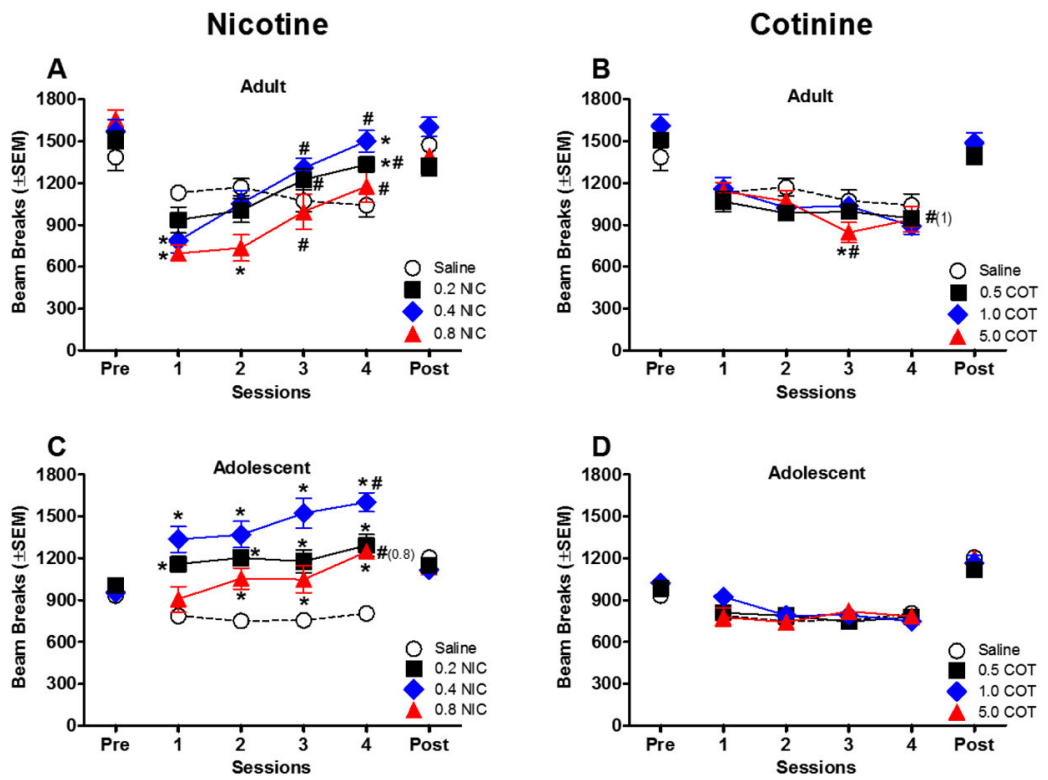

Figure 5.

Effects of nicotine and cotinine on locomotor activity during conditioning sessions. Data from adults are shown in panels A-B, and data from adolescents are shown in panels C-D $(n=10$ /group except adolescent 0.2 nicotine $n=14)$ * indicates a significant difference from the saline group (dose $\times$ session interaction), and \# indicates a significant difference from the first session for the same dose group (dose $\times$ session interaction). Numbers in parenthesis highlight doses with significant effects. Pre stands for pre-conditioning and post stands for post-conditioning. 

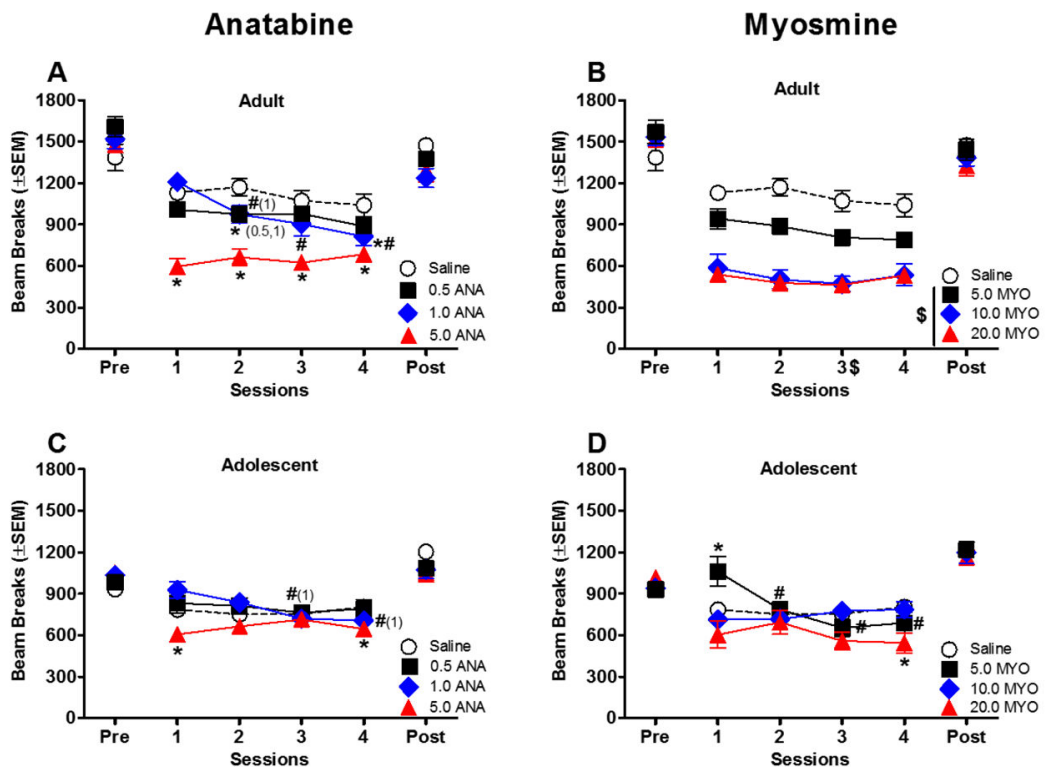

Figure 6.

Effects of anatabine and myosmine on locomotor activity during each conditioning session. Data from adults are shown in panels A-B, and data from adolescents are shown in panels C$\mathrm{D}$ ( $\mathrm{n}=10$ /group). * indicates a significant difference from the saline group (dose $\times$ session interaction), and \# indicates a significant difference from the first session for the same dose group (dose $\times$ session interaction). \$ indicates a significant main effect of dose or session as shown in the legend and $\mathrm{x}$ axis, respectively. Numbers in parenthesis highlight doses with significant effects. 

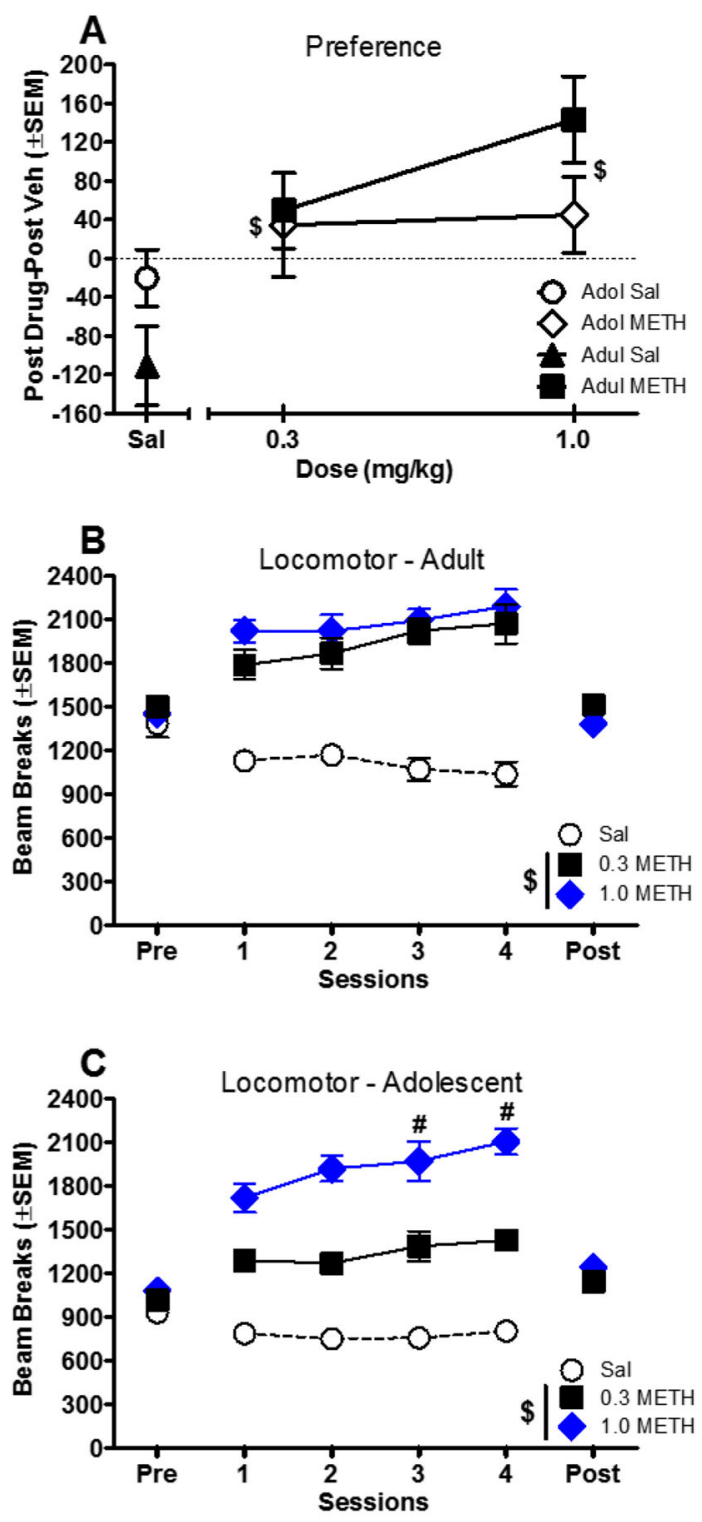

Figure 7.

Panel A shows preference for methamphetamine calculated as time spent in drug side minus time spent in vehicle side during the post-conditioning test. Panels B and C show effects of methamphetamine on locomotor activity during conditioning sessions for adults and adolescents, respectively ( $n=8$ /group except that sal $n=10$ /group). $\$$ indicates a significant difference from saline (main effect of dose). \# indicates a significant difference from the first session for the same dose group (dose $\times$ session interaction). 